\title{
EFFICACY OF EARLY PHYSICAL THERAPY FOR DIFFERENT BIRTH WEIGHT INFANTS AND ASSESSMENT OF THEIR MOTOR SKILL DEVELOPMENT
}

Margarita Senkutė, Ernesta Sendžikaitė, Alfonsas Vainoras

\author{
Lithuanian University of Health Sciences, Medical Academy, Kaunas, Lithuania
}

\begin{abstract}
Research background and hypothesis. The survey was conducted to determine impact of physical therapy on different birth weight babies with specific motor development function delay and muscle spasticity. Our research hypothesis was that physical therapy would affect baby motor development regardless of their birth weight.

Research aim. The aim of this study was to assess motor development of the infants with different birth weight before and after early physical therapy.

Research method. Forty nine infants were assessed with Munich Functional Development Diagnostic Assessment during their first year of life. This scale helps to assess the basic motor functions: crawling, sitting, walking, grasping, language speech, perception and social development in the first months of infant life. Also, this method helps to identify potential problems and to give the infant the required support. The results were compared with the standard.

Research results. The results indicated that the motor function (crawling, sitting, walking and grasping) of infants with very low and normal birth weight statistically significantly differed before physical therapy. Walking motor development differences for infants with very low and low birth weight were statistically significant $(p<0.05)$. The results showed that after physical therapy there was no significant difference in the motor development of infants with very low and normal weight in crawling and sitting $(\mathrm{p}>0.05)$. After physical therapy we noticed that there was no significant difference between walking and grasping development in babies with very low, low and normal weight $(\mathrm{p}>0.05)$.

Discussion and conclusions. Summarizing the results we suggest that specific motor development function delay and muscle spasticity in babies with different birth weight before physical therapy was significantly different in such motor functions as crawling, sitting, walking and grasping dependently on birth weight. After physical therapy, we also observed $80 \%$ of motor development improvement for very low birth weight, $45 \%$ development improvement for low birth weight, and 60\% development improvement for normal weight infants.
\end{abstract}

Keywords: spastic muscle, specific motor function development delay.

\section{INTRODUCTION}

$\mathrm{O}$ ne of the most important periods in child development is infancy. The behavioral and lifestyle characteristics of this period determine the quality of future life. M. Schertz et al. (2008) say that early childhood skills are the basis of future life, so early disease prevention is very important. The first year of life is particularly important for child development. Development of each child is individual, but development in general follows certain patterns. The genetic and emotional factors, social environment, diet influences baby movements, sensations, feelings and thinking, which is the psychomotor development. The internal factors are very important too. The most important factor is muscular activity. Muscular activity stimulates nerve center activity which produces an impact on brain weight and susceptibility to information. Movement is an important way of understanding the world. It promotes the growth of child's physical and mental development (Schertz et al., 2008). 
In the first year of life, it is very important to develop the correct performance of movements because motor skills are very important in the development of mental abilities. Good mobility influences fine motor training, develops will and discipline. There is a new capacity that arises every month, so it is recommended to check baby's psychomotor development from neonatal period during the first year of life. Knowing normal development helps to understand developmental delays. With regard to the normal development stages, the motor retardation can be noticed; you may plan correction programs and monitor the progress of development (Symington, Pinelli, 2006).

All over the world people pay much attention to research on the evaluation of child development. Almost all development delays can be observed during the first year of life in infants, the pediatricians and families are most attentive, and they are the ones to notice the problems first (Zeitlin et al., 2001).

Solving problems like treatment, rehabilitation, health promotion and disease prevention includes applying physical therapy. Many authors argue that the proper selection of exercises reduces the symptoms of disease progression (Docherty, 2002; Koscielny, 2004). All the time we question what the appropriate exercises are. It is always difficult to answer what physical exercise is the best for babies.

Contemporary research literature suggests that the development of motor functions and the importance of education is a holistic approach. It is very important to find development delays at the right time and to give the right correction according to baby's development. Physical therapist is responsible for the development of motor training, but they should collaborate with other specialists in early rehabilitation services team (neurologists, speech therapists, psychologists, social workers) (Mockevičienè, 2003).

Normal physiological spastic muscle stays still till 4 months of age (Hellbriegge, 2001), but sometimes, because of prematurity, very low birth weight, mother's medical condition during pregnancy, infections, malnutrition, environmental factors, genetic disorders, muscle spasticity can persist for a longer period of time (Tecklin, 2008; Ahmadpour-Kacho, 2011).

Different authors have different opinions about motility. M. Montessori (2000) states that motility is an ability to express feelings and sensation through the muscle. S. A. Manacero et al. (2011) argue that mobility is a conscious interaction between active muscle movements; it depends on the development of nervous system (Manacero et al., 2011). Normal motor development during infancy shows a normal nervous system function, so diagnosing it is very important (Belthur et al., 2003).

Muscle tone is involuntary muscle tension which in fast and passive limb flexion and extension feels resistance. Muscle tone depends on age, condition, central nervous system damage and so on. Muscle tone provides body position in space, creates muscle tension, thus helping to perform the movement (Petrikonis, 2005). It determines the central nervous system and biomechanical properties of muscle. Spasticity is the most common muscle change problem (Futagi, Suzuki, 2010).

Prematurity is a complex problem. C. J. Geldof et al. (2011) point out that as baby is born early, the birth weight is lower and there is a bigger risk of various developmental disorders. The congenital factors and environmental effects influence preterm birth (Geldof et al., 2011).

Premature infant development for babies of all age which are born with low weight is worse in all life periods compared to normal birth weight babies. Motor development disorders correlate with low birth body weight (Rimdeikienè et al., 2008).

We think that motor development of very low birth weight babies is worse than that of normal birth weight babies, and that physical therapy will help to improve motor development for normal, low and very low weight babies.

\section{RESEARCH METHODS}

Subjects. The research participants were 49 four - twelve-month-old infants ( 25 girls and 24 boys). All research participants had spastic muscle and specific motor function development delay. Subjects were divided into three groups (Dunn, 1986):

1. Very low birth weight infants (The birth weight was less than $1500 \mathrm{~g}(\mathrm{n}=11)$, age $31.20 \pm 7.91$ weeks).

2. Small birth weight infants (The birth weight was more than 1500 and less than $2500 \mathrm{~g}(\mathrm{n}=9)$, age $-24.78 \pm 5.67$ weeks).

3. Normal birth weight infants (The birth weight was more than $2501 \mathrm{~g}(\mathrm{n}=29)$, age $-26.33 \pm 8.08$ weeks). 
Procedure. All participants came to the early rehabilitation service. Each of them had 16 individual sessions of physical therapy 2-3 times a week. Physical therapy took about 1.5-2 months. Before and after physical therapy the infants were assessed by the Munich Functional Development scale (this methodology was approved in Lithuania in 2000, December 14, by the Ministry of Health). Physical therapy for all groups was conducted according to the infant's age by a physical therapist. We used Bobath methods while working with babies. The aim of Bobath methods is to teach and to develop correct movement during active motor development and normalize muscle tone. This scale evaluates the baby motility during the first year of life: crawling, sitting, walking, grasping, perception, speech perception, speech and social development. This scale helps to identify potential problems and to provide the required assistance to the child (Hellbriegge et al., 2001). Munich functional diagnostic rate is 0 , and if the number is negative, and it means that infant's development is worse than normal.

Mathematical statistics. The research data were processed using Microsoft Excel 2007 and Statistical Package for the Social Sciences (SPSS). The data are reported as group mean values \pm standard deviation (SD). The means were evaluated using Student's ( $t)$ test $(\mathrm{p}<0.05$ level of significance). Hypothesis of normal distribution of test characteristics were tested using Shapir-Wilk test. Comparing the quantity data distributed under the normal distribution we used nonparametric rank analysis. We used Wilcoxon criterion for two dependent samples checking the reliability of signs difference. We evaluated the reliability of difference for independent samples using MannWhitney criterion.

\section{RESEARCH RESULTS}

As we see in Figure 1, crawling motor development before physical therapy of normal and very low birth weight groups was significantly different $(\mathrm{p}<0.05)$. Results after physical therapy for the normal and low birth weight babies showed significant difference $(\mathrm{p}<0.05)$ (Figure 1).

The results during first screening of very low and normal birth weight baby's sitting development showed significant different $(\mathrm{p}<0.05)$. After physical therapy we noticed that sitting development of low and normal weight babies was significantly different, too $(\mathrm{p}<0.05)$ (Figure 2).

The evaluation of the walking development before physical therapy showed that walking development of very low weight babies was statistically significantly different from that of low and normal birth weight babies $(\mathrm{p}<0.05)$. After physical therapy walking development did not statistically differ between groups (Figure 3).

The examination of the grasping development before physical therapy showed statistically significant difference between normal and very low birth weight infants $(p<0.05)$. At the end of research the results showed that grasping development after physical therapy improved for all infants $(\mathrm{p}<0.05)$.

\section{DISCUSSION}

Since 1992 the state reorganization prenatal help programs have been carried out in Lithuania. After those programs more infants with low birth weight survived (Gaižauskienè et al., 1996). Premature infant health problems lead to functional organ and systems immaturity. Motor development

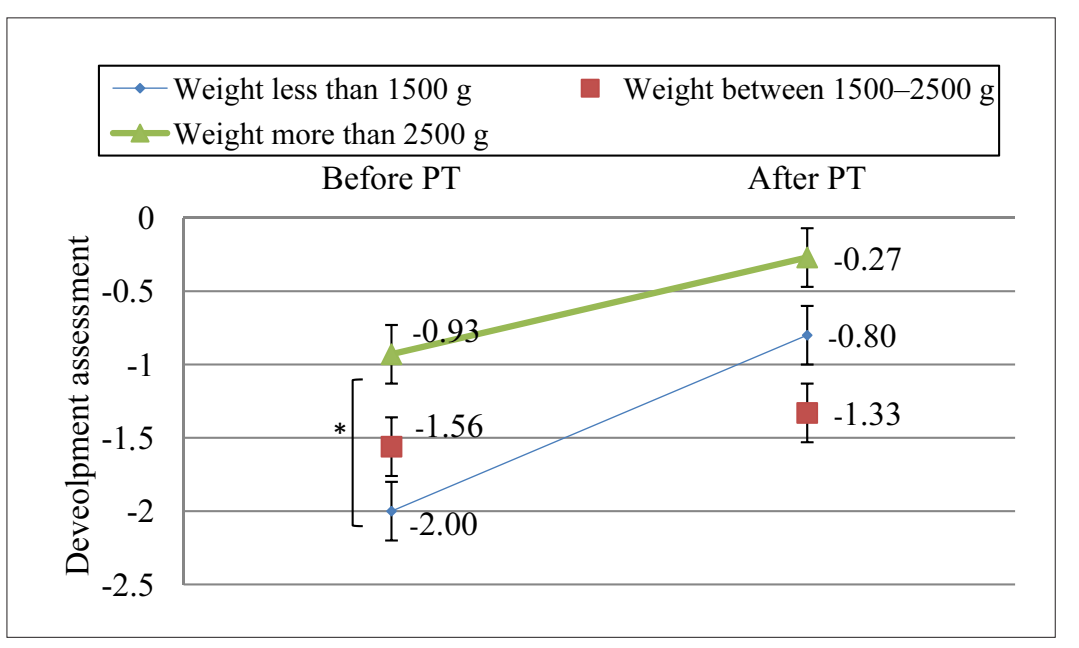

Figure 1. Crawling development evaluation in different birth weight infant groups

Note. * - significant differences between groups $\mathrm{p}<0.05$. 
of very low birth weight infants delay stays till the subsequent periods of growth (Heathcock et al., 2008). In Lithuania there are about 5.3\% - 1600 preterm births every year and $0.9 \%-300$ of them have very low birth weight.

A. Scianni etal. (2009) says that physical therapy is very important complex education in the first
Figure 2. Sitting development eva-luation in different birth weight infant groups

Note. * - significant differences between groups $\mathrm{p}<0.05$.

Figure 3. Walking development evaluation in different birth weight infant groups

Note. * - significant differences between groups $\mathrm{p}<0.05$.

Figure 4. Grasping up development evaluation in different birth weight infant groups

Note. $*$ - significant differences between groups $\mathrm{p}<0.05$.

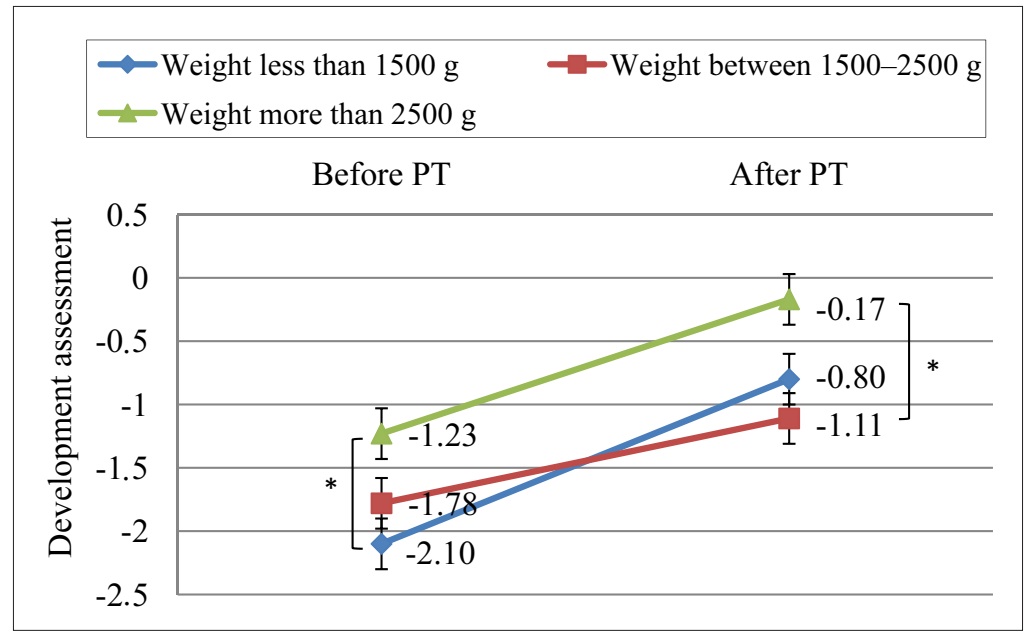

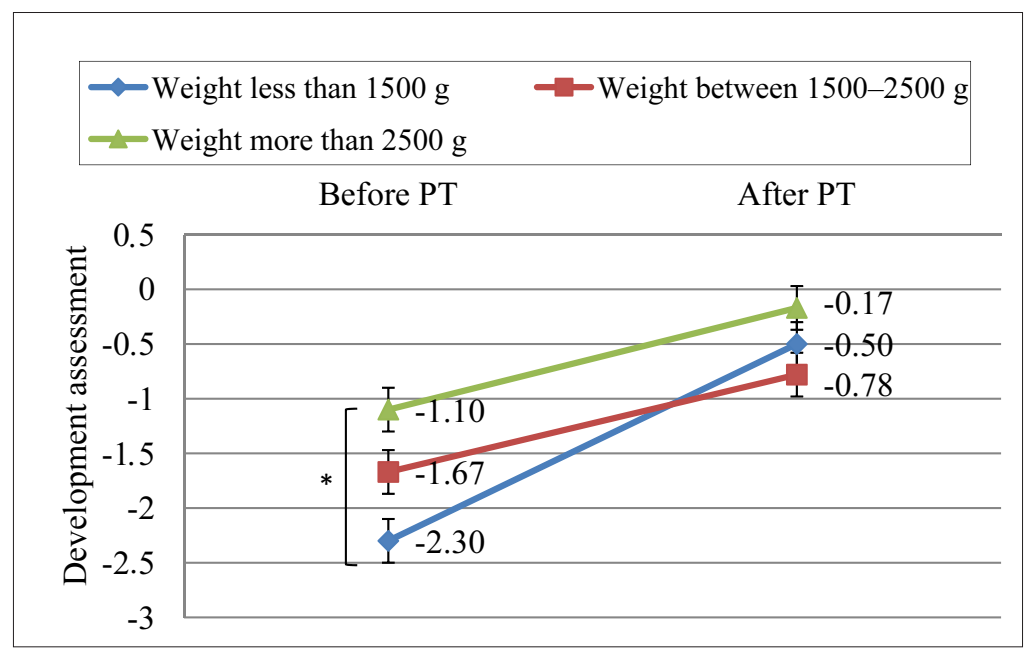


year of life and it affects psychomotor development. Many authors argue that early physical therapy can produce good results even for babies with severe disorders (Gorter et al., 2009). I. Rimdeikienè et al. (2008) claims that very low and low weight infant development is worse than that of normal birth weight babies, and our research showed the same. A. Scianni (2009), I. Rimdeikienè (2008) proved that motor development accelerated after applying physical therapy for very low, low and normal birth weight babies. Our results showed that physical therapy improved motor development for infants with specific motor development function delay and muscle spasticity.

Many authors agree that physical therapy in first year of life is particularly important for child development. Our results showed that before physical therapy normal birth weight infant's motor development was better than that of very low and low birth weight infant's motor development. However, no one showed normal development according to Munich Function Development Diagnostic Assessment even before or after physical therapy. However, the biggest development changes after physical therapy were observed in very low birth weight infants. We think that motor development of such babies is better because all systems developing very fast, and physical therapy is very important, too.

Motor development of normal and very low weight babies: crawling, sitting, walking and grasping significantly improved after physical therapy. Low weight group improvement was observed just in grasping development $(\mathrm{p}<0.05)$.

Summarizing the results we suggest that specific motor development function delay and muscle spasticity different of birth weight babies before physical therapy was significantly different in motor function - crawling, sitting, walking and grasping was dependent on birth weight). After physical therapy we noticed $80 \%$ of motor development improvement for very low birth weight, $45 \%$ development improvement for low birth weight, and $60 \%$ development improvement for normal weight infants.

Finally we would like to suggest to start physical therapy as soon as possible for babies with very low and low birth weight.

\section{CONCLUSIONS AND PERSPECTIVES}

Summarizing the results we noticed $80 \%$ motor development improvement for very low birth weight, $45 \%$ development improvement for low birth weight, and $60 \%$ development improvement for normal weight infants. Future research is needed to ascertain whether a specific developmental disability movement persists in school-age children.

\section{REFERENCES}

Ahmadpour-Kacho, M., Pasha, Y. Z., Aliabadi, B. M. (2011). Outcomes of very low birth weight infants after discharge with a discharge weight of 1500 grams. Pediatrics International: Official Journal of the Japan Pediatric Society, 54 (2), 196-199.

Belthur, M. V., Clegg, J., Strange, A. (2003). A physiotherapy specialist clinic in paediatric orthopaedics: Is it effective? Postgraduate Medical Journal, 79, 699702.

Docherty, D., Brandenburg, J. P. (2002). The effects of accentuated eccentric loading on strength, muscle hypertrophy, and neural adaptations in trained individuals. Journal of Strength and Conditioning Research, 16 (1), 25-32.

Dunn, H. (1986). Squeal of Low Birth-Weight: The Vancouver Study. Canada: Mac Keith Press.

Futagi, Y., Suzuki, Y. (2010). Neural mechanism and clinical significance of the plantar grasp reflex in infants. Pediatric Neurology, 43 (2), 81-86.

Gaižauskienè, A., Vezbergienè, N., Badikonyte, M., Isakova, J. (1996). Data of Medical Birth Register in Lithuania. Vilnius.
Geldof, C. J., Van Wassenaer, A. G., De Kieviet, J. F., Kok, J. H., Oosterlann, J. (2011). Visual perception and visual - motor integration in very preterm and/or very low birth weight children: A meta - analysis. In Research in Developmental Disabilities. Amsterdam: VU University Amsterdam.

Gorter, J. W, Verschuren, O., van Riel, L., Ketelaar, M. (2009). The relationship between spasticity in young children (18 months of age) with cerebral palsy and their gross motor function development. $B M C$ Musculoskeletal Disorders. Ontario, 4 (10), 108.

Heathcock, C. J., Lobo, M., Galloway, J. (2008). Movement training advances the emergence of reaching in infants born at less than 33 weeks of gestational age: A randomized clinical trial. Physical Therapy, 88 (3), 310-322.

Hellbriegge, T., Lajos F. I., Menara D. (2001). Munich Functional Development Diagnostics. The First Year of Life. Germany.

Koscielny, R. (2004). Strength training with cerebral palsy. Cerebral Palsy Magazine, 2 (1), 12-14.

Manacero, S. A., Marschik, P. B., Nunes, M. L., Einspieler, C. (2011). Is it possible to predict the 
infant's neurodevelopmental outcome at 14 months of age by means of a single preterm assessment of general movements? In Early Human Development. Brazil: Clinic Ceneffi, Porto Alegre.

Mickevičiene, D. (2003). Impaired Infant Movements Change with the Development of Remedial Education: PhD. Kaunas.

Montessori, M. (2000). Childhood Secrets. Kaunas.

Petrikonis, K. (2005). Spasticity treatment. Gydymo menas, 3, 3-5.

Rimdeikienė, I., Kriščiūnas, A., Markūnienè, E. (2008). Prematurely born infant psychomotor development evaluation. Medicina, 44 (5).

Schertz, M., Zuk, L., Zin, S. et al. (2008). Motor and cognitive development at one-year follow-up in infants with torticollis. Early Human Development, 84 (1), 9-14.

Scianni, A., Butler, J. M., Ada, L., Teixeira-Salmela, L. F. (2009). Muscle strengthening is not effective in children and adolescents with cerebral palsy: A systematic review. Australian Journal of Physiotherapy, 55 (2), 81-87.

Symington, A., Pinelli, J. (2006). Developmental Care for Promoting Development and Preventing Morbidity in Preterm Infants. Hamilton: Hamilton Health Sciences. Tecklin, S. (2008). Pediatric Physical Therapy. New York.

Zeitlin, J. A., Ancel, P. Y., Saurel-Cubizonlles, M. J., Papiernik, E. (2001). Are risk factors the same for small for gestational age versus other preterm birth? American Journal of Obstetrics and Gynecology, 185 (1), 208-215.

\title{
KINEZITERAPIJOS POVEIKIS SKIRTINGO GIMIMO SVORIO KŪDIKIŲ JUDAMAJAI RAIDAI
}

\author{
Margarita Senkutė, Ernesta Sendžikaitė, Alfonsas Vainoras \\ Lietuvos sveikatos mokslu universitetas, Medicinos akademija, Kaunas, Lietuva
}

\section{SANTRAUKA}

Tyrimo pagrindimas ir hipoteze. Tyrimas buvo atliekamas norint išsiaiškinti kineziterapijos poveiki skirtingo gimimo svorio kūdikiams, kuriems diagnozuotas specifinis judamosios funkcijos raidos sutrikimas ir raumenu hipertonusas. Iškẻlëme hipotezę, kad kineziterapija paveiks kūdikių judamają raidą nepriklausomai nuo ju gimimo svorio.

Tikslas - ¿̇vertinti skirtingo gimimo svorio kūdikių judamają raidą prieš kineziterapiją ir po jos.

Metodai. Buvo taikoma „Miuncheno funkcinè raidos diagnostika. Pirmieji gyvenimo metai“. Ši skale padeda pirmaisiais gyvenimo mènesiais ịvertinti pagrindines judamąsias funkcijas: ropojimą, sèdejimą, vaikščiojimą, griebimą ir kalbos suvokimą, kalbejjimą ir socialinę raidą. Taip pat šis vertinimo būdas padeda pakankamai anksti atpažinti galimus sutrikimus ir suteikti kūdikiui reikiamą pagalbą. Mūsų tyrimo rezultatai buvo palyginti su vertinimo standartu.

Rezultatai. Tyrimas parodè, kad prieš kineziterapiją labai mažo ir normalaus gimimo svorio kūdikių ropojimo, sèdèjimo, vaikščiojimo ir griebimo raida statistiškai patikimai skyrèsi, skirtumas pastebètas ir palyginus labai mažo bei mažo gimimo svorio kūdikių vaikščiojimo raidą $(p<0,05)$. Po kineziterapijos nustatyta, kad ropojimo ir sėdejjimo raidos ịvertinimas nesiskyre labai mažo bei normalaus gimimo svorio kūdikiu grupèse $(p<0,05)$, o vaikščiojimo ir griebimo raidos ìvertinimas nesiskyrè palyginus tiek labai mažo, mažo, tiek normalaus svorio kūdikių grupes $(\mathrm{p}>0,05)$.

Aptarimas ir išvados. Apibendrinus tyrimo rezultatus galima teigti, kad kūdikių, kuriems diagnozuotas speficinis judamosios funkcijos raidos sutrikimas ir raumenų hipertonusas, judamujų funkcijų (ropojimo, sèdèjimo, vaikščiojimo, griebimo) ivvertinimai prieš kineziterapiją skyrėsi priklausomai nuo gimimo svorio, o po kineziterapijos vertintų judamosios raidos komponentų pagerejimas nustatytas $80 \%$ labai mažo gimimo svorio, $45 \%$ mažo gimimo svorio ir 60\% normalaus gimimo svorio kūdikių.

Raktažodžiai: specifinis judamosios funkcijos raidos sutrikimas, raumenų hipertonusas.

Gauta 2011 m. lapkričio 30 d.

Received on November 30, 2011

Priimta $2012 \mathrm{~m}$. birželio $8 \mathrm{~d}$.

Accepted on June 8, 2012
Corresponding author Margarita Senkutè Lithuanian University of Health Sciences, Medical Academy

Jankaus str. 2, LT-50275 Kaunas

Lithuania

Tel +37061187035

E-mailmargariux@gmail.com 